\title{
Strengthening Integrity \& Preventing Corruption in the Judiciary in Kenya
}

\author{
Felix 0. Okiri', Lynn Waithera Ngugi², James Opiyo Wandayi ${ }^{3}$ \\ ${ }^{1}$ Law Reporting, Law Africa, Nairobi, Kenya \\ ${ }^{2}$ Litigation Department, Ahmednasir, Abdikadir \& Company Advocates, Nairobi, Kenya \\ ${ }^{3}$ National Assembly, Parliament of Kenya, Nairobi, Kenya \\ Email: okirifelix@gmail.com
}

How to cite this paper: Okiri, F. O., Ngugi, L. W., \& Wandayi, J. O. (2019). Strengthening Integrity \& Preventing Corruption in the Judiciary in Kenya. Beijing Law Review, 10, 131-152.

https://doi.org/10.4236/blr.2019.101008

Received: December 8, 2018

Accepted: February 15, 2019

Published: February 18, 2019

Copyright $\odot 2019$ by author(s) and Scientific Research Publishing Inc. This work is licensed under the Creative Commons Attribution International License (CC BY 4.0).

http://creativecommons.org/licenses/by/4.0/

\begin{abstract}
This study sought to underscore the central role of morals and ethics in reducing judicial corruption. The paper proceeded to study the concepts of integrity and corruption. Subsequently, the paper studied Kenya's development and current law on integrity, public service and corruption and possible areas for reform. The study found out that despite near-adequate legislations, Kenya's jurisprudence depicts a state of despair, lack of good will and numerous constraints in the anti-corruption process: many of the cases prosecuted in court have either been terminated by the courts or have not succeeded as a result of lack of political good will and political interference. The paper concluded that corruption is not only a legal issue but also a moral one-that is why major solutions to taming judicial corruption have flopped as a result of the linear approach to offering solutions. The paper found out that in order to offer formidable solutions to corruption in the judiciary, the legislative and policy approaches ought to be structured and conceptualized in a more realistic and feasible manner to that of ordinary obligations and offences. As a central point of interest, premium must be attached to integrity, as a moral concern, in order to offer sustainable solution to corruption in the judiciary.
\end{abstract}

\section{Keywords}

Reducing Judicial Corruption

\section{Introduction, Scope, Concept, the Law and the Current Judicial Environment}

\subsection{Introduction}

In 1973, Charles R. Ashman wrote a book titled: The Finest Judges Money Can 
Buy: And Other Forms of Judicial Pollution. ${ }^{1}$ In this book, Charles recounted that the American justice was choking of judicial pollution. He further documented court cases as proof that corruption trends were no longer a question of occasional corruption, but a decided pattern of chronic bribery, conflict of interest, profound abuse of office, infamous sexual perversions, loathsome nepotism and pernicious payoffs. ${ }^{2}$ As a result of this tendency, the author was of the view that the American public could no longer retain an attitude of vacant apathy as incorrigible corruption was bound to destroy the effectiveness of the American system of justice. ${ }^{3}$

In England, Sir Francis Bacon is quoted to have said the following "Judicial corruption and fraud are prevalent in the judicial system. ${ }^{4}$ I usually accept bribes from both sides so that tainted money can never influence my decision." (Bacon \& Montagu, 1859) ${ }^{5}$ In Kenya, Justice Mutava in Republic v Attorney General \& 3 others Ex-parte Kamlesh Mansukhlal Damji Pattni $1^{6}$ reiterated the sentiments of Chief Justice Willy Mutunga who stated that "we count our losses, drop the corruption cases and stop throwing good money after bad. KACC should initiate public discussions and seek national consensus."

From the above sentiments, it's evident that judiciaries over the world have experienced episodes of corruption. As will be proved herein, these episodes range from small scale to massive. What's of interest is-in the words of Charles R. Ashman, "No judge is outrageously corrupt by himself. For every judge that money can buy there must be buyers and brokers. Most of the judicial corrupters are relatives of judges, practicing lawyers or their predatory intermediaries." ${ }^{\prime 8} \mathrm{He}$ further asserts that "in this country (America), we believe, or at least claim to believe, in equality before the law. But those who have the money or the contacts, or both, exert a judicial pressure that eliminates equality and promotes a double standard of justice. For there are those who stand before the bar relying only on their lawyers and their hopes. And there are those whose cases are more clandestinely and hurriedly resolved by a fix."

These concerns point to the facts that: judicial corruption is real; the corruption process has certain dominant players. Charles R. Ashman further asserts that: "those who claim there is no Mafia in this country are either disastrously ignorant or members in good standing. Organized crime cannot function with-

${ }^{1}$ Charles R. Ashman, The Finest Judges Money Can Buy. And Other Forms of Judicial Pollution, 1973.

${ }^{2}$ Ibid.

${ }^{3}$ Ibid.

${ }^{4}$ Charlayne Grenci Behind Closed Doors French-Flair Publishing, 11 Apr 2017.

${ }^{5}$ Francis Bacon, Basil Montagu The Works of Francis Bacon, Lord Chancellor of England: With a Life of the Author by Basil Montagu, Volume 1 Parry \& McMillan, 1859.

${ }^{6}$ Republic v Attorney General \& 3 others Ex-parte Kamlesh Mansukhlal Damji Pattni [2013] eKLR at paragraph 92.

${ }^{7}$ Ibid.

${ }^{8}$ Charles R. Ashman, The Finest Judges Money Can Buy. And Other Forms of Judicial Pollution, 1973. (supra)

${ }^{9}$ Ibid. 
out 'organized justice."'10 Charles believes that judicial corruption sprouts and thrives in a "corruption fertile judiciary" (Ashman, 1973). ${ }^{11}$

However, this proposition of corruption only thriving in a "corruptible environment" is not entirely correct. Seymour R. Thaler, a New York Supreme Court Justice-Elect was convicted March 23, 1972 of judicial corruption. When asked about what motivated him to engage in corruption, he said "I have no excuse. I was just greedy" (Tolchin, \& Tolchin, 2015). ${ }^{12}$ According to William H. Rehnquist, informed by experience, "if a presumption is made that a judge will always seize every opportunity presented to him to be corrupt, no canon of ethics or statute regarding disqualification can save our judicial system" (Rehnquist, 1973). ${ }^{13}$ What this implies is that: judicial corruption or lack of it may be a result of either-corruptibility of the judiciary (low remuneration, corruptible processes, and non-transparent recruitment process) and personal judge ethics among others.

This paper seeks to underscore the central role of morals and ethics in reducing judicial corruption. Morals have been defined to mean-the social contract itself; what we all agree we should do i.e. the "public consensus" or generally what the public believes to be good (Dieter, 2013). ${ }^{14}$ Ethics on the flip are-the integrity (soundness/correctness) of our private decisions, e.g. what we choose to do when no one is looking and we are reasonably certain our actions will not be discovered (Goodstein, 2000). ${ }^{15}$ From the above definitions, it is evident that integrity is the York. From integrity sprouts ethics, and from ethics sprouts morals. It is from this analogy that Pahis, Stratos asserted that- "judiciary without integrity has little chance of executing its moral and constitutional duties, no matter how many rules of ethics exist" (Stratos, 2009). ${ }^{16}$

With the benefit of experience, it has been concluded that-every decision to grant a motion, to follow precedent, to interpret a statute or facts, to set a sentence or damages-which is at the discretion of a judge-is a potential opportunity for corruption. ${ }^{17}$ To this extent therefore, eliminating all opportunities for personal gain is not a simple task. ${ }^{18}$ Pahis, Stratos narrates that "such a task would require nothing less than the destruction of the independent and adaptable judicial system we know .... ${ }^{19}$ and so we count on honest judges to navigate ${ }^{10}$ Ibid.

${ }^{11}$ Ibid.

${ }^{12}$ Martin Tolchin, Susan J. Tolchin Pinstripe Patronage (Routledge, 22 Dec 2015).

${ }^{13}$ William H. Rehnquist, Sense and Nonsense About Judicial Ethics, 28 Rec. 694 (1973).

${ }^{14}$ Dieter Birnbacher Moral and Other Values, 2013

<http://kulturaiwartosci.umcs.lublin.pl/wp-content/uploads/2014/06/Dieter_Birnbacher_Moral_and Other_Values3.pdf $>$ Accessed $15^{\text {th }}$ January 2017.

${ }^{15}$ Jerry D. Goodstein "Moral Compromise and Personal Integrity: Exploring the Ethical Issues of Deciding Together in Organizations" [2000] 10 (4) (Business Ethics Quarterly

$<$ https://www.jstor.org/stable/3857834> Accessed 15 ${ }^{\text {th }}$ January 2017.

${ }^{16}$ Pahis, Stratos. "Corruption in Our Courts: What It Looks like and Where It Is Hidden" [2009] 118(8) The Yale Law Journal 1900-1943<http://www.jstor.org/stable/40389524> Accessed $26^{\text {th }}$ Sept. 2017.

${ }^{17}$ ibid.

${ }^{18}$ Ibid, Inference.

${ }^{19}$ Ibid. 
our ship of justice through these dangerous waters." ${ }^{20}$

The India Apex Court in Tarak Singh vs. Jyoti Basu, ${ }^{21}$ affirmed that "Integrity is the hallmark of judicial discipline ... it is high time the judiciary took utmost care to see that the temple of justice does not crack from inside, which will lead to a catastrophe in the judicial-delivery system resulting in the failure of public confidence in the system. It must be remembered that woodpeckers inside pose a larger threat than the storm outside." ${ }^{22}$ Smriti Every couches the notion of integrity in these words "The judges appointed by the king should be well versed in procedure, wise, of good character and temperament, soft in speech, impartial to friend or foe, truthful, learned in law, active (not lazy), free from anger, greed, or desire (for personal gain), and truthful. ${ }^{23}$

From the above excerpts, case law and analogy, this paper makes a preliminary finding that integrity is at the heart of prevention of corruption. The paper therefore seeks to deconstruct the concepts of integrity and corruption and further establish the relationship between the two. This analogy will also be guided by historical cases and considerations of corruption in Kenya. The paper will also review Kenya's law on corruption. This multi-factor evaluation approach will be important in discovering the gaps in law, approach, processes or otherwise so as make viable proposals in revamping the judicial process by strengthening integrity and preventing corruption.

\subsection{Scope}

Generally, the process of strengthening integrity and preventing corruption is largely a legal issue. This paper will therefore analyze the anti-corruption laws in Kenya with a view to identifying the loopholes if any and how these loopholes can be sealed. The paper will also determine whether other factors apart from the law affect judicial corruption.

Specifically, this paper will research on: the concept of integrity and corruption; Kenya's anti-corruption legislative and survival history; the current law on integrity, public service and corruption and whether there is any need for reform; lessons from the past-how Kenya has failed in the process of curbing corruption; and finally some suggestions to preventing corruption.

\subsection{The Concept of Integrity and Corruption}

\subsubsection{Integrity}

The Blacks' Law Dictionary defines integrity as a term which means-soundness of moral principle and character, as shown by one person dealing with others in the making and performance of contracts, and fidelity and honesty in the discharge of trusts. The term is synonymous with "probity," "honesty," and

${ }^{20}$ Ibid.

${ }^{21}$ Tarak Singh vs. Jyoti Basu, (2005) 1 SCC 201.

${ }^{22}$ Ibid.

${ }^{23}$ Justice S. S. Dhavan The Indian Judicial System A Historical Survey

$<$ http://allahabadhighcourt.in/event/TheIndianJudicialSystem_SSDhavan.doc $>$ accessed $28^{\text {th }}$ Sept. 2017. 
"uprightness". ${ }^{24}$ The Oxford English Dictionary also defines integrity as-the quality of being honest and having strong moral principles. ${ }^{25}$

From a philosophic perspective, the concept "integrity" connotes a unity of parts that constitute a whole. ${ }^{26}$ The integers, for example, represent an enumeration of multiple whole units, whether they are chairs or people (Westra \& Lemons, 2012). ${ }^{27}$ The Latin adjective integer meant intact, whole, complete, perfect and honest. ${ }^{28}$ Integrity was a way of complimenting the well-known probity of the classical Roman character. ${ }^{29}$ The verb "to integrate," connotes making, strengthening, or adding to a whole by bringing appropriate parts into appropriate union with one another. ${ }^{30}$ As a value concept, integrity is a desirable characteristic in human personalities. In this respect, what lacks integrity may be considered as being dishonest, corrupt, incoherent, ugly, degraded, or ready to fail or disintegrate. ${ }^{31}$

The draft Kenya Judicial Code of Conduct ${ }^{32}$ provides that-integrity is essential to the proper discharge of the judicial office. ${ }^{33}$ The Code further provides that-a judge shall ensure that his or her conduct is above reproach in the view of a reasonable observer; ${ }^{34}$ the behavior and conduct of a judge must reaffirm the people's faith in the integrity of the judiciary and a judge shall uphold the principle that Justice must not merely be done but must also be seen to be done $e^{35}$; a judge shall not use the judicial office to improperly enrich himself, herself or other person; ${ }^{36}$ a judge shall not knowingly permit a member of judicial staff or other person subject to the judge's influence, direction or authority, to ask for, or accept, any gift, loan, hospitality, advantage, privilege or favor in relation to anything done or to be done or omitted to be done in connection with his or her duties or functions. ${ }^{37}$

The Bangalore Principles of Judicial Conduct provides that-Integrity is essential to the proper discharge of the judicial office. ${ }^{38}$ The above document fur-

\footnotetext{
${ }^{24}$ Black, Henry C, and Joseph R. Nolan. Black's Law Dictionary: Definitions of the Terms and Phrases of American and English Jurisprudence Ancient and Modern; [with Pronunciations]. St. Paul, Minn: West Publ, 1993.

${ }^{25}$ OED Online, Oxford University Press, June 2017, $<$ http://www.oed.com/;jsessionid=8AB9E47B780F832ECB611859A80BE937?authRejection=true\&ur l=\%2Fviewdictionaryentry\%2FEntry\%2F11125> Accessed 25 September 2017.

${ }^{26}$ Angela Ramsey Practical Leadership BookBaby, 22 Aug. 2015.

${ }^{27}$ L. Westra, J. Lemons Perspectives on Ecological Integrity Springer Science \& Business Media, 6 Dec. 2012 page 225 .

${ }^{28}$ Ibid.

${ }^{29} \mathrm{Ibid}$.

${ }^{30}$ See Merriam Webster Online Dictionary

$<$ http://www.learnersdictionary.com/definition/integrate $>$ accessed $29^{\text {th }}$ Sept. 2017.

${ }^{31}$ L. Westra, J. Lemons Perspectives on Ecological Integrity Springer Science \& Business Media, 6 Dec 2012 page 225.

${ }^{32}$ IDLO \& Kenya Judiciary Training Institute Judicial Code of Conduct $<$ http://www.judiciary.go.ke/portal/assets/filemanager_uploads/Downloads/Draft\%20Judicial\%20Co de\%20of\%20Coduct.pdf $>$ accessed on $26^{\text {th }}$ Sept. 2017.

${ }^{33}$ Ibid. Section 3 (1).

${ }^{34}$ Ibid Section 3 (2).

${ }^{35}$ Ibid Section 3 (3).

${ }^{36}$ Ibid Section 3 (4).

${ }^{37}$ Ibid Section 3 (5).

${ }^{38}$ The Bangalore Principles Of Judicial Conduct, 2002 Value 3.
} 
ther provides that-to attain this integrity, a judge shall ensure that his or her conduct is above reproach in the view of a reasonable observer. ${ }^{39}$ The commentary to the Bangalore Principles of Judicial Conduct ${ }^{40}$ affirms that-a judiciary of undisputed integrity is the bedrock of democracy and the rule of law. ${ }^{41}$ Even when all other protections fail, the judiciary provides a bulwark to the public against any encroachments on rights and freedoms under the law (UNODC, 2001). ${ }^{42}$

The Indian Code of Conduct for Judges provides that-a judge should maintain and enforce high standards of conduct and should personally observe those standards, so that the integrity and independence of the judiciary may be preserved. ${ }^{43}$ In K. P. Singh vs. High Court of H. P. \& ors, ${ }^{44}$ Justice Kurian Joseph, C. J. stated that "Integrity according to Oxford dictionary is moral uprightness; honesty. It takes in its sweep, probity, innocence, trustfulness, openness, sincerity, blamelessness, immaculacy, rectitude, uprightness, virtuousness, righteousness, goodness, cleanness, decency, honor, reputation, nobility, irreproachability, purity, respectability, genuineness, moral excellence etc. In short, integrity depicts sterling character with firm adherence to a code of moral values." ${ }^{35}$

\subsubsection{Corruption}

In the words of Sun $\mathrm{Zu}$, “. $\ldots$ in warfare, victories are won by those who understand and know the moves of their enemy" (Sun Tzu, 1953). ${ }^{46}$ Loosely applied, for anti-corruption efforts to be successful, the concept of corruption must be understood in-depth (Heeks, 2011). ${ }^{47}$ It is documented that most anti-corruption initiatives in developing countries fail. This is because our anti-corruption remedies do not consist of a generic design approach that if applied will create success. The remedies that have been applied have been described as "a form of oversimplification and one size fits all approach." This has led anti-corruption interventions off track. ${ }^{48}$

According to Black's Law Dictionary, corruption is an illegality which is a vicious and fraudulent intention to evade the prohibitions of the law. ${ }^{49}$ In $U . S . V$. Johnson, ${ }^{50}$ corruption was defined as an act where an official or fiduciary person unlawfully and wrongfully uses his station or character to procure some benefit 
for himself or for another person, contrary to duty and the rights of others. ${ }^{51}$

The legal definition of corruption is found in Section 2 of Anti-Corruption and Economic Crimes Act. ${ }^{52}$ The Act provides that corruption means: an offence under any of the provisions of sections 39 (repealed) to 44 (bid rigging), 46 (Abuse of office) and 47 (Attempts, conspiracies)..$^{53}$ Other offences included are; bribery; fraud; embezzlement or misappropriation of public funds; abuse of office; breach of trust; or an offence involving dishonesty in connection with any tax, rate or impost levied under any Act; or under any written law relating to the elections of persons to public office. ${ }^{54}$ From an economic aspect, Vito Tanzi defines corruption as “... the intentional non-compliance with the arm's-length principle aimed at deriving some advantage for oneself or for related individuals from this behavior" (Begovic, 2005) ${ }^{55}$ From a moral perspective, corruption has been defined as acting unlawfully because of moral impurity and it is recognized as the deviation from an ideal (Tseki, 2014). ${ }^{56}$

From the broader concept of corruption, judicial corruption has been defined to mean the use of public authority for personal gain that results in an improper delivery of judicial services and legal protection for citizens (Pepys, 2003). ${ }^{57}$ This conceptualization of corruption and specifically judicial corruption is important in strategizing and establishing viable mechanisms of detection of corruption, investigation, prosecution, tracing and confiscating assets as a measure of prevention of similar acts of corruption.

\section{Kenya's Anti-Corruption Legislative and Survival History}

The Kenya Anti-Corruption website documents that Kenya has experienced a tumultuous history in the fight against graft. ${ }^{58}$ In 1956, the first statute dealing with corruption-The Prevention of Corruption Act ${ }^{59}$ was enacted. This statute was in operation from August 1956 to May 2003. ${ }^{60}$ Initially, this Act was enforced by the Anti-Corruption Squad under the Police Department, constituted in 1993. ${ }^{61}$ Regrettably, this Squad was however disbanded in 1995 before it could make any significant impact. ${ }^{62}$ Subsequently, the Police Anti-Corruption Squad was established as a force within the police force to spearhead the fight against ${ }^{51}$ Ibid.

${ }^{52}$ Anti-Corruption and Economic Crimes Act No. 3 Of 2003.

${ }^{53}$ Ibid. S. 2 (1)

${ }^{54}$ Ibid.

${ }^{55}$ Boris Begovic “Corruption: Concepts, Types, Causes, and Consequences” (2005) Center for International Private Enterprise Economic Reform Feature Service

<https://www.cipe.org/legacy/publication-docs/032105.pdf> accessed 27 $7^{\text {th }}$ Sept. 2017.

${ }^{56}$ Lebohang Tseki Corruption: A Moral Issue, 2014.

${ }^{57}$ Mary Noel Pepys Corruption and the Justice Sector January 2003.

${ }^{58}$ ICPAK The Current Challenges In Enforcing The Anti Corruption And Economic Crimes Act (Aceca)

<https://www.icpak.com/wp-content/uploads/2015/09/THE-Challenges-In-Enforcing-the-Anti-Corr uption-and-Economic-Crimes-Act.pdf $>$ accessed $16^{\text {th }}$ January, 2018.

${ }^{59}$ The Prevention of Corruption Act (formerly Cap. 65, LOK).

${ }^{60}$ Ibid.

${ }^{61}$ Ibid.

${ }^{62}$ Ibid. 
corruption. ${ }^{63}$ Regrettably again, this force was disbanded in $1995 .{ }^{64}$

In 1997, the Prevention of Corruption Act was amended with the effect that the amendment established the Kenya Anti-Corruption Authority (KACA). John Harun Mwau was subsequently appointed Director in December $1997 .{ }^{65}$ After only six months in office, Mwau was suspended and later removed in 1998. Justice Aaron G. Ringera was appointed to replace Mwau in March 1999. ${ }^{66}$ In 2000, KACA was disbanded after it was declared unconstitutional by the High Court in the case of Gachiengo $V$ Republic $^{67}$ on the basis that the powers of KACA to prosecute were against Section 26 of the then Constitution which preserved powers of prosecution on the Attorney General. ${ }^{68}$ In August 2001, the Anti-Corruption Police Unit (ACPU) was created by Executive Order. ${ }^{69}$ This organ operated under the Criminal Investigations Department (CID) of the Police and took over KACA's mandate in September 2001. ${ }^{70}$

In April 2003, Parliament enacted two pieces of legislation: -The Anti-Corruption and Economic Crimes Act (ACECA); ${ }^{71}$ and The Public Officer Ethics Act. ${ }^{72}$ Section 70 of the (ACECA) repealed the Prevention of Corruption Act. ${ }^{73}$ ACECA also established the Kenya Anti-Corruption Commission (KACC) as a body corporate, prescribing its composition and conferring powers and functions to it. ${ }^{74}$ Justice (Rtd.) Aaron G. Ringera, was subsequently appointed as its chairperson. In July 2009, Justice Ringera was forced to resign from office together with Ms. Sichale and Dr. Wanjala following parliamentary pressure. They paved the way for appointment of Prof. P. L. O. Lumumba to take office in September 2010. ${ }^{75}$

In 2011, Parliament disbanded KACC through enactment of the Ethics and Anti-Corruption Commission Act (EACC), 2011 pursuant to Article 79 of the Constitution. ${ }^{76} \mathrm{Mr}$. Mumo Matemu was subsequently appointed the Chairman and assumed office on 5th August 2013 after the Court of Appeal quashed an

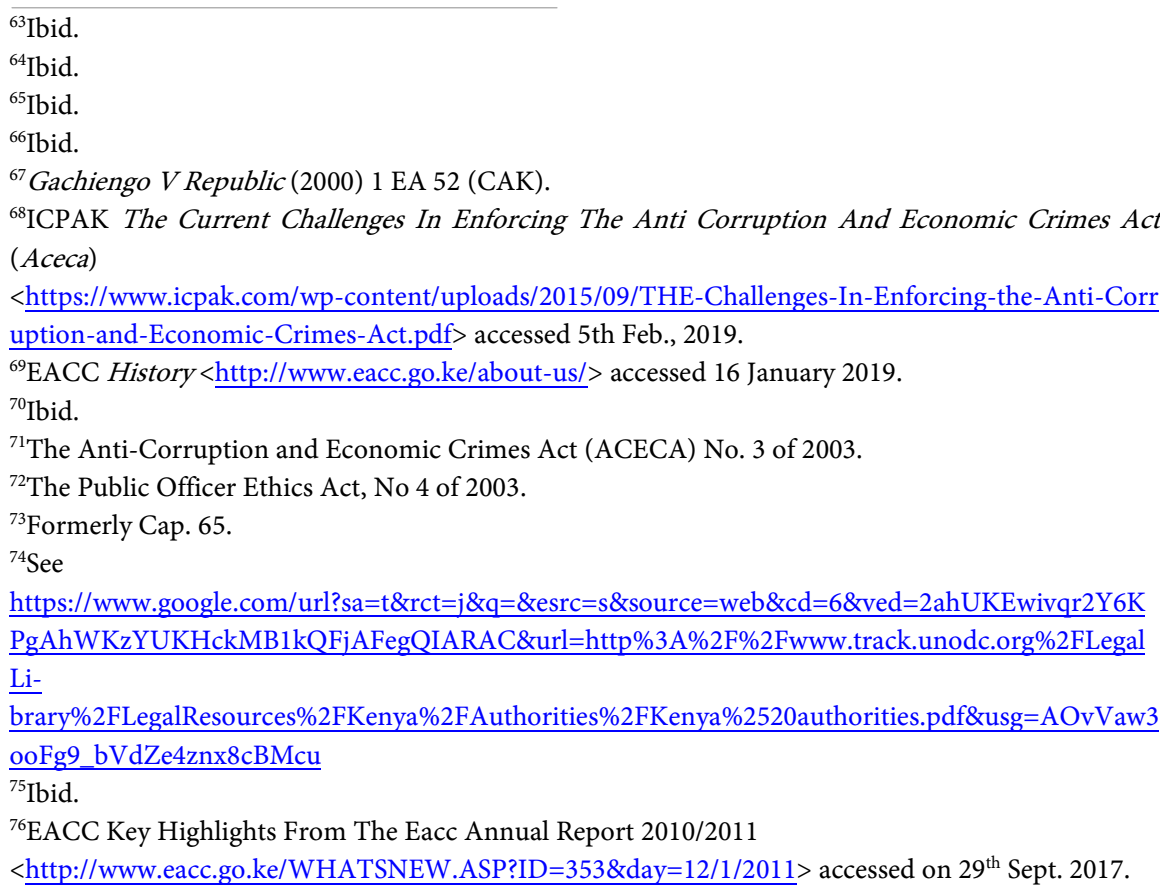


earlier ruling barring him from assuming office on claims of lacking integrity. ${ }^{77}$ Similar to the fate of other former anti-corruption officials, the Commission was deflated in 2015 when the Chairperson Mr. Mumo Matemu, Vice Chair Irene Keino, and Commissioner Jane Onsongo tendered their resignations as EACC Commissioners. $^{78}$

In November 2015, Mr. Philip K.B. Kinisu, was nominated as Chairman by President Uhuru Kenyatta. Other commissioners nominated were Sophia Lepuchirit, Dr. Dabar Maalim, Paul Gachoka, and Rose Mghoi-Macharia. These commissioners took oath of office in January, $18^{\text {th }} 2016 .{ }^{79}$ In August 31,2016 , The Ethics and Anti-Corruption Commission (EACC) chairman Philip Kinisu bowed to pressure and resigned yet again derailing the commission's efforts in fighting corruption. ${ }^{80}$

\section{The Status of Corruption in Kenya}

As this paper will prove, the fluid nature of corruption has made anti-corruption efforts a "try and see" process. This implies that the anti-corruption laws have either been partly correct, incorrect or completely unsure. Similar concerns have been made by stakeholders. ${ }^{81}$ For example in 2005, just 2 years after President Kibaki took office with the promise to fight corruption, and after successfully foreseeing the enactment of The Anti-Corruption and Economic Crimes Act, 2003, key diplomatic missions expressed skepticism over the commitment and the pace of President Kibaki's Government in fighting corruption. ${ }^{82}$

According to Transparency International, no country got close to a perfect score in the Corruption Perceptions Index 2016. ${ }^{83}$ Over two-thirds of the 176 countries and territories in 2016 corruption index fell below the midpoint of a scale of 0 (highly corrupt) to 100 (very clean). The global average score was paltry 43 , indicating endemic corruption in a country's public sector..$^{84}$ Out of the 176 countries gauged by The Transparency International report, Kenya was

\footnotetext{
${ }^{77}$ MumoMatemu $v$ Trusted Society of Human Rights Alliance \& 5 others [2013] eKLR.

${ }^{78}$ Caroline Wafula "Key Ethics and Anti-Corruption Commission official Jane Onsongo quits over infighting” Daily Nation Tuesday March 312015

<https://www.nation.co.ke/news/politics/EACC-Jane-Onsongo-Resignation/1064-2672198-11yce86z /index.html> accessed $28^{\text {th }}$ Sept. 2017.

${ }^{79}$ EACC Commissioners's wearing in

<http://www.eacc.go.ke/twalib-abdallah-mbarak-takes-oath-of-office-as-eacc-secretary-chief-executi ve-officer/> accessed on $29^{\text {th }}$ Sept. 2017

${ }^{80}$ ObedSimiyu "Kinisu bows to pressure, resigns as EACC chairman" (Daily Nation, Wednesday August 31 2016)

<http://www.nation.co.ke/news/Ethics-Anti-Corruption-Commission/1056-3364272-xedwjez/index. html $>$ accessed on $28^{\text {th }}$ Sept. 2017.

${ }^{81}$ Tom Mogusu and Benson Kathuri "Kenya: Diplomats Say They Are Unsure Corruption War is Being Fought" Allafrica <http://allafrica.com/stories/200504120126.html $>$ accessed on $28^{\text {th }}$ Sept 2017.

${ }^{82}$ Ibid.

${ }^{83}$ Transparency International Corruption Perceptions Index 2016

<http://www.ey.com/Publication/vwLUAssets/EY-Transparency-International-Corruption-Percepti ons-Index-2016/\$FILE/EY-Transparency-International-Corruption-Perceptions-Index-2016.pdf> accessed $27^{\text {th }}$ Sept. 2017.

${ }^{84}$ Ibid.
} 
ranked at number 145 down from 139 in 2015 scoring 26 points out of $100{ }^{85}$ Ironically, the report noted that Kenya's poor performance came despite the adoption of a few anti-corruption measures including passing a law on the right to information (Transparency International, 2016). ${ }^{86}$

\section{The Current Law on Integrity, Public Service and Corruption-Any Need for Reform?}

In summary, this section sets out to discuss the anti-corruption laws in Kenya. The section will thus analyze the relevant laws and investigate their propriety in preventing and or solving judicial corruption.

\subsection{Constitution of Kenya, 2010}

The Constitution provides that the national values and principles of governance in this Article bind all State organs, State officers, public officers and all persons whenever any of them applies or interprets this Constitution; enacts, applies or interprets any law. ${ }^{87}$ Such authority assigned to a State officer is a public trust to be exercised in a manner that brings honor to the nation and dignity to the office; and promotes public confidence in the integrity of the office. ${ }^{88}$ The exercise of such authority shall be in conformity with the national values and principles of governance which include good governance, integrity and transparency. ${ }^{89}$

State officer shall behave, whether in public and official life, in private life, or in association with other persons, in a manner that avoids any conflict between personal interests and public or official duties; compromising any public or official interest in favor of a personal interest; or demeaning the office the officer holds. ${ }^{90}$ Article 76 provides that a gift or donation to a State officer on a public or official occasion is a gift or donation to the Republic and shall be delivered to the State unless exempted under an Act of Parliament. ${ }^{91}$ Equally, a State officer shall not: maintain a bank account outside Kenya except in accordance with an Act of Parliament; or seek or accept a personal loan or benefit in circumstances that compromise the integrity of the State officer. ${ }^{92}$ A person who contravenes Article 76, 77 shall be subject to the applicable disciplinary procedure for the relevant office; and may, in accordance with the disciplinary procedure be dismissed or otherwise removed from office..$^{93}$ A person who has been dismissed or otherwise removed from office for a contravention of the provisions above is disqualified from holding any other State office. ${ }^{94}$

Article 79 mandates Parliament to enact legislation to establish an Indepen-

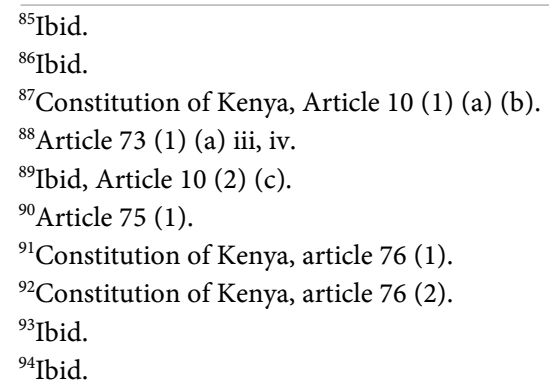


dent Ethics and Anti-corruption Commission. This Commission shall have the status and powers of ensuring compliance with, and enforcement of, the provisions of chapter six of the constitution on leadership and integrity. ${ }^{95}$ In compliance with this Constitutional provision, parliament has enacted the Ethics and Anti-Corruption Commission Act. ${ }^{96}$

\subsection{Ethics and Anti-Corruption Commission Act, No 22 of 2011}

The Preamble of this Act states that-the Act is-an Act of Parliament to establish the Ethics and Anti-Corruption Commission pursuant to Article 79 of the Constitution, to provide for the functions and powers of the Commission, to provide for the qualifications and procedures for the appointment of the chairperson and members of the Commission, and for connected purposes. ${ }^{97}$ The aim of this paper is to discern to what level the Act if at all is structured to strengthen integrity and prevent corruption.

In addition to the functions of the Commission under Article 252 and Chapter Six of the Constitution, the Commission shall, in relation to State officers; develop and promote standards and best practices in integrity and anti-corruption; develop a code of ethics; work with other State and public offices in the development and promotion of standards and best practices in integrity and anti-orruption; receive complaints on the breach of the code of ethics by public officers; investigate and recommend to the Director of Public Prosecutions the prosecution of any acts of corruption or violation of codes of ethics or other matter prescribed under this Act or any other law enacted pursuant to Chapter Six of the Constitution; recommend appropriate action to be taken against State officers or public officers alleged to have engaged in unethical conduct; and oversee the enforcement of codes of ethics prescribed for public officers. ${ }^{98}$

\subsection{Bribery Act, 2016}

The Preamble of this Act states that it is an Act of Parliament to provide for the prevention, investigation and punishment of bribery, and for connected purposes. ${ }^{99}$ This Act establishes the offence of bribe and the scenarios under which bribery may occur. The Act categorizes bribery as an Act of giving or taking a bribe. ${ }^{100} \mathrm{~A}$ person commits the offence of giving a bribe if the person offers, promises or gives a financial or other advantage to another person, who knows or believes the acceptance of the financial or other advantage would itself constitute the improper performance of relevant function or activity. ${ }^{101} \mathrm{~A}$ person commits the offence of receiving a bribe if the person requests, agrees to receive or receives a financial or other advantage intending that, in consequence, a rele-

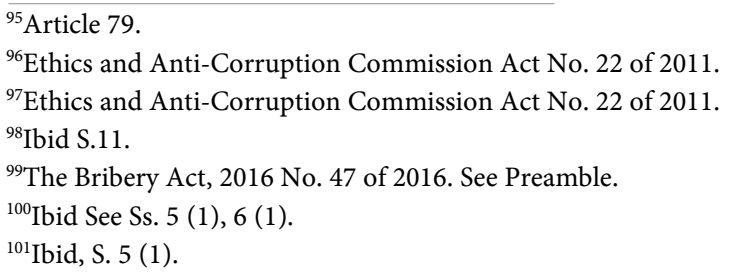


vant function or activity should be performed improperly whether by that person receiving the bribe or by another person. ${ }^{102}$

This Act also imposes a duty to public or private entities to have in place procedures for the prevention of bribery. The Act states that a public or private entity shall put in place procedures appropriate to its size and the scale and to the nature of its operation, for the prevention of bribery and corruption. ${ }^{103}$ Every state officer, public officer or any other person holding a position of authority in a public or private entity also have a duty to report to the Commission within a period of twenty-four hours any knowledge or suspicion of instances of bribery. ${ }^{104}$

\subsection{Leadership and Integrity Act, 2015}

The Preamble of this Act states that it is an Act of Parliament to give effect to, and establish procedures and mechanisms for the effective administration of Chapter Six of the Constitution and for connected purposes. ${ }^{105}$ The Act enumerates the guiding values, principles and requirements of state officers. ${ }^{106} \mathrm{~A}$ State officer shall respect the values, principles and the requirements of the Constitution, including: the national values and principles provided for under Article 10 of the Constitution; the rights and fundamental freedoms provided for under Chapter Four of the Constitution; the responsibilities of leadership provided for under Article 73 of the Constitution; the principles governing the conduct of State officers provided for under Article 75 of the Constitution; the educational, ethical and moral requirements in accordance with Articles 99 (1) (b) and 193 (1) (b) of the Constitution; and in the case of County governments, the objectives of devolution provided for under Article 174 of the Constitution. ${ }^{107}$

The Act mandates every State officer to respect and abide by the Constitution and the law. ${ }^{108}$ The Act states that a State officer shall carry out the duties of the office in accordance with the law. ${ }^{109}$ In carrying out the duties of his office, a State officer shall not violate the rights and fundamental freedoms of any person unless otherwise expressly provided for in the law and in accordance with Article 24 of the Constitution. ${ }^{110}$ Such an officer is also mandated to uphold impartiality and objectivity in accordance with Articles 10, 27, 73 (2) (b) and 232 of the Constitution and shall not practice favoritism, nepotism, tribalism, cronyism, religious bias or engage in corrupt or unethical practices. ${ }^{111}$

In the performance of their duties, a State officer shall, to the best of their ability carry out the duties of the office efficiently and honestly, carry out the du-

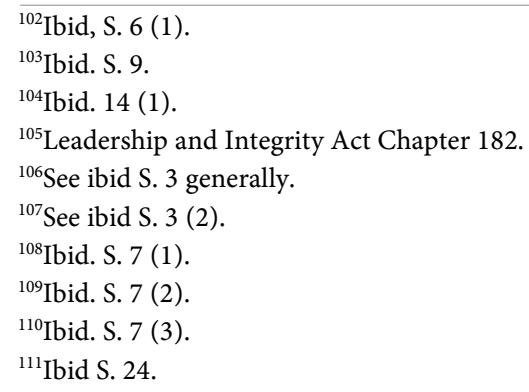


ties in a transparent and accountable manner; keep accurate records and documents relating to the functions of the office; and report truthfully on all matters of the organization which they represent. ${ }^{112}$ In so doing, a State officer shall uphold professionalism by carrying out duties of the office in a manner that maintains public confidence in the integrity of the office; treat members of the public and other public officers with courtesy and respect; not discriminate against any person, except as is expressly provided by the law; and maintain high standards of performance and level of professionalism within the organization. ${ }^{113}$

With regards to financial integrity, a State officer shall not use the office to unlawfully or wrongfully enrich himself or herself or any other person. ${ }^{114}$ In accordance with Article 76 (2) (b) of the Constitution, a State officer shall also not accept a personal loan or benefit which may compromise the State officer in carrying out his duties. ${ }^{115}$ Any gift or donation given to a State officer on a public or official occasion shall be treated as a gift or donation to the State. ${ }^{116}$

The Act also prescribes some moral and ethical requirements. ${ }^{117}$ In accordance with Articles 99 (1) (b) and 193 (1) (b) of the Constitution, a person shall observe and maintain the following ethical and moral requirements: demonstrate honesty in the conduct of public affairs subject to the Public Officer Ethics Act (No. 4 of 2003); not to engage in activities that amount to abuse of office; accurately and honestly represent information to the public; not engage in wrongful conduct in furtherance of personal benefit; not misuse public resources; not discriminate against any person, except as expressly provided for under the law; not falsify any records; not engage in actions which would lead to the State officer's removal from the membership of a professional body in accordance with the law. ${ }^{118}$

\subsection{Anti-Corruption and Economic Crimes Act, 2003}

The preamble to this Act provides that it is an Act of Parliament to provide for the prevention, investigation and punishment of corruption, economic crime and related offences and for matters incidental thereto and connected therewith. ${ }^{119}$

Section. 2 of The Act defines corruption as: an offence under any of the provisions of sections 39 (repealed) to 44 (bid rigging), 46 (Abuse of office) and 47 (Attempts, conspiracies). ${ }^{120}$ Other offences included are; bribery; fraud; embezzlement or misappropriation of public funds; abuse of office; breach of trust; or an offence involving dishonesty in connection with any tax, rate or impost levied under any Act; or under any written law relating to the elections of persons to

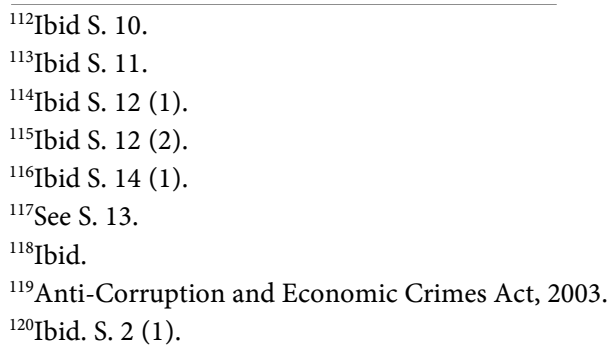


public office. Other offences included are; bribery; fraud; embezzlement or misappropriation of public funds; abuse of office; breach of trust; or an offence involving dishonesty in connection with any tax, rate or impost levied under any Act; or under any written law relating to the elections of persons to public office. ${ }^{121}$

As it has been noted above, the main objectives of the Act were to provide for the prevention, investigation and punishment of corruption and economic crimes. The objectives were to a larger extent visionary. However, the attainment of those objectives has not been easy. This paper will analyze some of those challenges in the realization of the objectives of the Anti-Corruption and Economic Crimes Act as a depicture of the complexity in the prevention and curbing of corruption.

\subsection{Public Officer Ethics Act Cap 183}

The preamble to this Act provides that it is an ACT of Parliament to advance the ethics of public officers by providing for a Code of Conduct and Ethics for public officers and requiring financial declarations from certain public officers and to provide for connected purposes. ${ }^{122}$ The Act states that a public officer shall carry out his duties in accordance with the law. ${ }^{123}$ Such an officer shall not use his office to improperly enrich himself or others. ${ }^{124}$ Improper enrichment connotes - requesting or receiving gifts or favors from a person who has an interest that may be affected by the carrying out, or not carrying out, of the public officer's duties; improperly use his office to acquire land or other property for himself or another person, whether or not the land or property is paid for. ${ }^{125}$

\subsection{Judicial Code of Conduct}

The draft Kenya Judicial Code of Conduct ${ }^{126}$ provides that the Code is intended to give effect to Articles 168 (1) (b) and 172 (1) (c) of the Constitution; give effect to the Bangalore Principles of Judicial Conduct as adopted by the Judicial Group on Strengthening Judicial Integrity, and revised at the Round Table Meeting of Chief Justices held at the Peace Palace. ${ }^{127}$ Broadly, the Code provides for the below thematic areas: A Code of conduct for judges; Code of conduct for judicial officers; the code of conduct for members of judicial staff; Oversight over judicial conduct and resolution of complaints. ${ }^{128}$

\section{- Code of conduct for judges}

With regards to the Code of conduct for judges, the code provides an elabo-

${ }^{121}$ Ibid.

${ }^{122}$ The Public Officer Ethics Act, 2003 Chapter 183. See preamble.

${ }^{123}$ Ibid, S. 10.

${ }^{124}$ Ibid, S. 11.

${ }^{125}$ Ibid, S. 11 (2).

${ }^{126}$ IDLO \& Kenya Judiciary Training Institute Judicial Code of Conduct

<http://kenyalaw.org/kl/fileadmin/pdfdownloads/LegalNotices/2016/132-JudicialServiceAct_Judicial CodeofConductandEthics__2016.pdf $>$ accessed on 5th February, 2019.

${ }^{127}$ Ibid, S. 3 (2).

${ }^{128}$ See Part II, III, IV, V of the Code. 
rate code entailing provisions on independence, impartiality, integrity, propriety, equality and non-discrimination, professionalism, accountability and prohibition against corrupt practices and prohibition against sexual harassment. ${ }^{129}$

The Code states that judicial independence is a constitutional requirement to the rule of law and a fundamental guarantee of a fair trial and a judicial officer shall therefore uphold and exemplify independence in both individual and institutional capacities. ${ }^{130}$ It further provides that a judicial officer shall exercise the judicial authority independently on the basis of the judicial officer's assessment of the facts and in accordance with a conscientious understanding of the law, free of any extraneous influences, inducements, pressures, threats or interference, direct or indirect, from any quarter or for any reason. ${ }^{131} \mathrm{~A}$ judicial officer shall equally not deviate from the law to appease public clamor, to avoid criticism, or to advance an illegitimate interest. ${ }^{132}$

The Code defines impartiality as a requirement that a judicial officer shall make decisions based on objective criteria, rather than on the basis of bias, prejudice or conferring the benefit to one person over another for improper reasons. ${ }^{133}$ The Code requires that a judicial officer shall be impartial in order to properly discharge his judicial functions. To this extent, he shall promote impartiality not only to the decision itself but also to the process by which the decision is made. ${ }^{134} \mathrm{~A}$ judicial officer shall neither initiate nor consider ex parte communications on the merits, or procedures affecting the merits of a proceeding that is before, or could come before, the judicial officer except as authorized by law. ${ }^{135}$

Integrity has been recognized as an essential component to the proper discharge of the judicial office. ${ }^{136} \mathrm{~A}$ judicial officer shall ensure that his or her conduct is above reproach in the view of a reasonable observer. ${ }^{137} \mathrm{~A}$ judicial officer shall not use the judicial office to improperly enrich himself, herself or other person. ${ }^{138} \mathrm{He}$ shall also not knowingly permit a member of judicial staff or other person subject to the judicial officer's influence, direction or authority, to ask for, or accept, any gift, loan, hospitality, advantage, privilege or favor in relation to anything done or to be done or omitted to be done in connection with his or her duties or functions. ${ }^{139}$

A judicial officer shall ensure that his actions are proper. The Code requires that in his or her personal relations with individual members of the legal profession who practice regularly in the courts, avoid situations which might reasona- 
bly give rise to the suspicion or appearance of favoritism or partiality. ${ }^{140} \mathrm{He}$ shall also not use or lend the prestige of the judicial office to advance the private interests of the judicial officer, a member of the judicial officer's family or of anyone else, nor shall a judicial officer convey or permit others to convey the impression that anyone is in a special position improperly to influence the judicial officer in the performance of judicial duties. ${ }^{141}$

A judicial officer shall refrain from financial and business dealings that tend to reflect adversely on the judicial officer's impartiality, interfere with the proper performance of judicial duties, exploit the judicial office, or involve the judicial officer in transactions with lawyers and other persons likely to come before the court in which the judicial officer serves. ${ }^{142}$

Equality and non-discrimination has also been recognized in the Code. It states that ensuring equality of treatment to all before the courts is essential to the due performance of the judicial office. ${ }^{143} \mathrm{~A}$ judicial officer shall not, in the performance of judicial duties, by words or conduct, manifest bias or prejudice towards any person or group on irrelevant grounds. ${ }^{144}$

A judicial officer shall also embrace professionalism by maintaining order and decorum in all proceedings before the court and be patient, dignified and courteous in relation to litigants, witnesses, lawyers and others with whom the judicial officer deals in an official capacity. The judicial officer shall require similar conduct of advocates, court staff and other persons before the court. ${ }^{145} \mathrm{~A}$ judicial officer shall not engage in conduct incompatible with the diligent discharge of judicial duties. ${ }^{146}$

On accountability and prohibition against corrupt practices, a judicial officer is mandated to perform his or her judicial duties without favor, bias or prejudice and shall not be influenced by any improper motive or corrupt practice. ${ }^{147}$ In the performance of judicial functions, a judicial officer or any member of the judicial officer's family, shall neither ask for, nor accept, any bribe, gift, loan, hospitality, advantage, privilege or favor in relation to anything done or to be done or omitted to be done by the judicial officer in connection with the performance of judicial duties, or which might reasonably be perceived as being intended to influence the performance of judicial duties. ${ }^{148}$

The Code also guards against sexual harassment. It states that a judicial officer shall not sexually harass a fellow staff or any other person in the workplace, or other professional or social situation. ${ }^{149}$

- The code of conduct for members of judicial staff

\footnotetext{
${ }^{140}$ Ibid. S. 4 (5).

${ }^{141}$ Ibid. S. 4 (8).

${ }^{142}$ Ibid. S. 4 (11).

${ }^{143}$ Ibid. S. 5 (1).

${ }^{144}$ Ibid. S. 5 (3).

${ }^{145}$ Ibid. S. 6 (7).

${ }^{146}$ Ibid. S. 6 (8).

${ }^{147}$ Ibid. S. 7 (3).

${ }^{148}$ Ibid. S. 7 (2).

${ }^{149}$ Ibid. S. 8.
} 
The Code enumerates certain ethical standards that members of judicial staff are mandated to comply with. The Act covers, among other standards-performance of duties by judicial staff, confidentiality, conflict of Interest, prohibition of improper enrichment, accountability and prohibition against corrupt practices and prohibition of sexual harassment. ${ }^{150}$

Briefly, a judicial staff member shall at all times perform official duties properly and to the utmost of his or her ability and with diligence, and shall commit themselves exclusively to the business and responsibilities of the office during working hours. ${ }^{151}$ On confidentiality, a judicial staff member shall not disclose to any unauthorized person any confidential information acquired while employed in the judiciary, whether such information came from authorized or unauthorized sources. ${ }^{152} \mathrm{~A}$ judicial staff member shall avoid conflicts of interest in the performance of official duties. Judicial staff member is required to exercise utmost alertness on conflicts of interest, and shall disclose conflicts to an appropriate authority, and terminating them when they arise. ${ }^{153}$

With regards to improper enrichment, a judicial staff member shall not request or accept any fee, compensation, or benefit of any kind, as a condition for the performance of his or her duties, for himself or herself or on behalf of any person, on account of anything done or omitted to be done by him or her in the discharge of the duties of his or her office. ${ }^{154} \mathrm{~A}$ judicial staff member or any member of the Judicial staff member's family, shall neither ask for, nor accept, any bribe, gift, loan, hospitality, advantage, privilege or favor in relation to anything done or to be done or omitted to be done by the Judicial staff member in connection with the performance of judicial duties, or which might reasonably be perceived as being intended to influence the performance of judicial duties. ${ }^{155}$ A judicial staff member shall not sexually harass a fellow staff or any other person in the workplace, or other professional or social situation. ${ }^{156}$ Where sexual harassment includes exerting unwarranted pressure for sexual activity or favors. ${ }^{157}$

\section{Lessons from the Past: How Kenya Has Failed in the Process of Curbing Corruption-Legal or Moral Issue?}

Kenya's jurisprudence depicts a state of despair, lack of good will and numerous constraints in the anti-corruption process. As it shall be evidenced, many of the cases prosecuted in court have either been terminated by the courts or have not succeeded as a result of lack of political will and political interference.

\subsection{Judicial Attitudes to Dealing with Corruption in Kenya}

The success or not of the judiciary in the fight against corruption can be con-

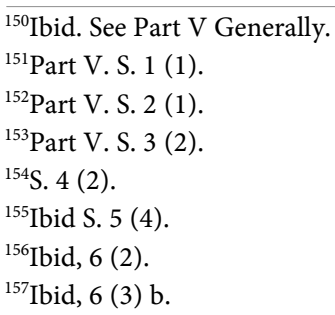


cluded from the jurisprudence so far developed by the courts arising from various cases. The answer to the issue above is based on an evaluation of the various approaches and attitudes of the courts in adjudicating corruption cases. This section thus inquires on the court's jurisprudence with special regards to the application and interpretation of the anti-corruption laws.

As it shall be evidenced herein, Kenyan courts have interpreted the legislation on corruption in a way that gives the language of the statute an extremely narrow and restrictive interpretation and thereby defeated the intention of the legislation (Owiny, 2009) ${ }^{158}$ This was the case in Gachiengov. Republic ${ }^{159}$ where the High Court interpreted the Constitution in a manner that made the Prevention of Corruption Act inconsistent with the Constitution thereby rendered the Act void. ${ }^{160} \mathrm{~A}$ similar decision is the case of Republic v. The judicial Commission of Inquiry into the Goldenberg Affair \& Others Exparte George Saitoti ${ }^{161}$ where the three Judge Bench concluded upon hearing the main application that the Commission had in its remarks, findings, and conclusions regarding the applicant made errors of fact and law and granted the prayers sought. The effect of this was that it served as a major blow to the prosecution and the efforts to fight corruption.

In Republic v Attorney General \& 3 others ${ }^{162}$, Justice Mutava made an order prohibiting the Respondents and/or any other authority from prosecuting or continuing to prosecute the Applicant and his associated companies including Goldenberg International Limited in Nairobi Chief Magistrates Court Criminal Case No. 518 of $2006^{163}$. In his ruling, the judge was guided by sentiments of then Chief Justice Willy Mutunga "We are either serious (on old graft cases) or count our losses, drop them and stop throwing good money after bad. KACC should initiate public discussions and seek national consensus"164. Similarly, the then Director of KACC is quoted to have said "Old corruption cases must be finalized. Goldenberg cases are in court. We will not be prisoners of our past, but the rear view mirror will be in us" ${ }^{165}$ The above ideas and decision signifies a resigned attitude/approach in addressing corruption cases.

Similar judicial attitude towards the fight against corruption have been evidenced in the cases such as BVLtd Vs KACC \$AG, Midland Finance and Security Ltd, Nairobi Petition No. 390 of 2006, Nedemer technology NBI HOC Pet. No 359 of $2007 .{ }^{166}$ A common feature of these cases is that the courts have halted

${ }^{158}$ Owiny Patrick Efficacy Of The Policy, Legal And Institutional Frameworks For Combating Corruption In Kenya (2009).

${ }^{159}$ Gachiengov. Republic (2001 1EA67).

${ }^{160}$ ibid.

${ }^{161}$ Republic v. The judicial Commission of Inquiry into the Goldenberg Affair \& Others Exparte George Saitoti HC Misc.Civ.App.102 of 2006(The Saitoti Case).

${ }^{162}$ Republic v Attorney General \& 3 others Ex-parte Kamlesh Mansukhlal Damji Pattni [2013] eKLR.

${ }^{163}$ Goldenberg International Limited in Nairobi Chief Magistartes Court Criminal Case No. 518 of 2006.

${ }^{164}$ The Standard Newspaper 11th July 2011, Statements by Chief Justice Dr. Willy Mutunga.

${ }^{165}$ The Standard Newspaper 11th July 2011, Statements by the then KACC Director P.L.O Lumumba.

${ }^{166}$ Nedermar Technology Bv Ltd V Kenya Anti-Corruption Commission \& Another [2006] eKLR. 
investigations by KACC which in effect stopped investigations into the Anglo-leasing contracts on the ground that the contracts were of security nature and their investigation would jeopardize national security. ${ }^{167}$

\subsection{Other Challenges Impacting on Anti-Corruption Judicial Decisions}

\subsubsection{Political Challenges}

Corruption has a political dimension (James, 2010) ${ }^{168}$ In Republic v. The judicial Commission of Inquiry into the Goldenberg Affair \& Others Exparte George Saitot $1^{169}$ The Bosire Commission ${ }^{170}$ recommended that 14 individuals be either prosecuted or sued by the Attorney General in order for the government to recover the money lost in the Goldenberg Affair. ${ }^{171}$ Subsequently, the minister moved to court to block the impending prosecution. ${ }^{172} \mathrm{He}$, the minister (George Saitoti), was granted leave to file judicial review proceedings in bid to quash the findings, remarks and decisions in the Bosire Report. ${ }^{173}$ It is trite that political inter-meddling in economic crimes is a culture of the Kenya's body politic. The court in the Saitoti case granted the order to quash the Report on the basis that the Commission erred by purporting to review a decision of parliament which had concluded that Saitoti had acted in law. ${ }^{174}$ The court in fact went overboard to state that it was an abuse of the process of court similar to that in Stanley Munga Githunguri v. Republic ${ }^{175}$ Another classical case is the Anglo-leasing Case $^{176}$ charged involved a number of Kenyan government officials among them former vice-president Musalia Mudavadi. ${ }^{177}$ For their political influence, the case has not been substantively concluded.

However, Government has also shown political goodwill in fighting corruption. In Thuita Mwangi \& 2 others $v$ Ethics \& Anti-Corruption Commission \& 3 others ${ }^{178}$ the government supported the indictment of former foreign affairs permanent secretary Thuita Mwangi, former charge d'affaires of the embassy in Tokyo Allan Mburu, and the deputy director of administration at the Ministry of Foreign Affairs, Anthony Mwaniki Muchiri, on allegations of corruption in the 2010 procurement of the chancery and ambassador's residence in Tokyo. ${ }^{179}$ 


\subsubsection{Complexity of Corruption Cases}

Kenyan courts have found difficulties in logically adjudicating corruption cases because of the complex nature of corruption. ${ }^{180}$ Admittedly, corruption is complex. The complexity is neither in the law itself nor lack of it; it lies in the fluid nature of corruption as a vice. The corruption as was in 2003 is not the corruption in 2017. Corruption changes with technology, it changes with change of governments, corruption changes with morals, with age and so on. Higher levels of corruption, such as grand corruption, are complex in nature and need specialised skills to uncover. ${ }^{181}$ Sometimes the fight against corruption is a double-edged sword. When you uncover certain trends and deal with them, they can develop into more complex forms to tighten their grip. ${ }^{182}$ It is on this account that Justice Mutava in Republic $v$ Attorney General \& 3 others Ex-parte Kamlesh Mansukhlal Damji Pattni ${ }^{183}$ reiterated the sentiments of Chief Justice Willy Mutunga in stating that "we count our losses, drop the corruption cases and stop throwing good money after bad. KACC should initiate public discussions and seek national consensus".

In conclusion, as evidenced above, Kenya's jurisprudence shows that the courts are either unwilling, unable, overburdened or "over-controlled" in a manner that makes the success sum of the anti-corruption war meger. As a complex area of jurisprudence, future reforms in the judicial anti-corruption law ought to, if need be, center more on inculcating ethics and morals as a wholesome solution to addressing judicial corruption.

\section{Some Suggestions to Preventing Corruption}

The role of the judiciary, as an independent and equal branch of government, is to protect human rights and civil liberties by ensuring the right to fair trial (Canadian Judicial Council, 2016). ${ }^{184}$ This is the solemn call of justice in a democracy based on the rule of law (Antonin, 1989). ${ }^{185}$ Although the courts have this solemn role, many public opinion polls show that the public typically views the judicial branch as one of the most corrupt governmental institutions in their countries. ${ }^{186}$ The courts are therefore called upon to realize their high calling and consequently take their rightful place.

There is a general concern that reduction of systemic corruption in judicial systems without undermining judicial independence is not a simple matter

${ }^{180}$ Sam Koim "The challenges of fighting corruption in Papua New Guinea" (Development Policy Blog, $8^{\text {th }}$ Dec, 2014)

$<$ http://devpolicy.org/the-challenges-of-fighting-corruption-in-papua-new-guinea-20141208/> accessed $23^{\text {rd }}$ March, 2017.

${ }^{181}$ Ibid.

${ }^{182}$ Ibid.

${ }^{183}$ Supra note 5 at paragraph 92.

${ }^{184}$ Canadian Judicial Council Why Is Judicial Independence So Important To You?, 2016.

${ }^{185}$ Antonin, S 1989. The Rule of Law as a Law of Rules The University of Chicago Law Review 56 (4) $<$ https://pdfs.semanticscholar.org/956c/a176e52f3c1035511cb04a2747c02d83a9a2.pdf $>$ accessed $27^{\text {th }}$ Sept.2017.

${ }^{186} \mathrm{Ibid}$. 
(Gloppen, 2014). ${ }^{187}$ Judicial system corruption is a diverse phenomenon and requires a range of responses (Søreide \& Williams, 2013) ${ }^{188}$ From the legal analysis herein above, it is true that the enacted anti-corruption laws are adequate. ${ }^{189}$ The subsisting judicial corruption may thus not wholly be attributed to inadequacy or lack of laws. ${ }^{190}$ To this extent therefore, there is need to capitalize more on ethics and morals as a better pill to addressing judicial corruption.

One of the solutions to internal judicial corruption is engendering accountability of judges to the rules governing the systemic processes in the judiciary. This is informed by the realization that Kenya's jurisprudence shows that some of the courts are unwilling to perform their obligations.

There is also a concern that the judiciary is "over-controlled" by external political forces. This breach on the court's independence has made the success sum of the anti-corruption war merger. As a proposal therefore, reforms in the law ought to be made to make the judicial officers less accountable to the political players.

\section{Conclusion}

Corruption is huge, real, complex and cruel. Conceivably, it is more than a contravention of the law. It is a sin. Largely, solutions to taming judicial corruption have flopped. The analysis from this failure paints a picture of a failure as a result of the linear approach to offering solutions. Formidable solutions to judicial corruption must not be viewed from the perspective of obligations and offences. The issue must be deconstructed and solutions offered in a wholesome approach tendered by the centrality of integrity as a moral concern.

\section{Conflicts of Interest}

The authors declare no conflicts of interest regarding the publication of this paper.

\section{References}

Antonin, S. (1989). The Rule of Law as a Law of Rules. The University of Chicago Law Review, 56, 1175-1188. https://pdfs.semanticscholar.org/956c/a176e52f3c1035511cb04a2747c02d83a9a2.pdf

Ashman, C. R. (1973). The Finest Judges Money Can Buy: And Other Forms of Judicial Pollution. Los Angeles: Nash Publishing.

Bacon, F., \& Montagu, B. (1859). The Works of Francis Bacon, Lord Chancellor of England: With a Life of the Author by Basil Montagu. Boston: Parry \& McMillan.

Begovic, B. (2005). Corruption: Concepts, Types, Causes, and Consequences. Center for International Private Enterprise.

http://www.cipe.org/sites/default/files/publication-docs/032105.pdf

\footnotetext{
${ }^{187}$ Siri Gloppen Courts, corruption and judicial independence

$<$ https://www.cmi.no/publications/file/5091-courts-corruption-and-judicial-independence.pdf $>$ accessed on $29^{\text {th }}$ Sept. 2017.

${ }^{188}$ Tina Søreide, Aled Williams Corruption, Grabbing and Development: Real World Challenges Edward Elgar Publishing, 27 Dec 2013.

${ }^{189}$ Inference.

${ }^{190}$ Inference.
} 
Canadian Judicial Council (2016). Why Is Judicial Independence So Important to You? https://www.courts.gov.bc.ca/documents/Why_is_Judicial_Independence_Important_t o_You.pdf

Dhavan, S. S. The Indian Judicial System: A Historical Survey. http://allahabadhighcourt.in/event/TheIndianJudicialSystem_SSDhavan.doc

Dieter, B. (2013). Moral and Other Values. Delhi: NR Publishing House. http://kulturaiwartosci.umcs.lublin.pl/wp-content/uploads/2014/06/Dieter_Birnbacher _Moral_and_Other_Values3.pdf

Gloppen, S. (2014). Courts, Corruption and Judicial Independence. EEP Inc. https://www.cmi.no/publications/file/5091-courts-corruption-and-judicial-independen ce.pdf

Goodstein, J. D. (2000). Moral Compromise and Personal Integrity: Exploring the Ethical Issues of Deciding Together in Organizations. Business Ethics Quarterly, 10, 805-819. https://www.jstor.org/stable/3857834 https://doi.org/10.2307/3857834

Heeks, R. (2011). Understanding Success and Failure of Anti-Corruption Initiatives. https://www.google.com/url?sa=t\&rct=j\&q=\&esrc=s\&source=web\&cd=2\&cad=rja\&ua $\mathrm{ct}=8 \& v e d=0$ ahUKEwjCp-bH-MTWAhVG6RQKHdT8BdQQFggvMAE\&url=https\%3A \%2F\%2Fwww.research.manchester.ac.uk\%2Fportal\%2Ffiles\%2F25387977\%2FPOST-P EER-REVIEW-NON-PUBLISHERS.DOC\&usg=AFQjCNFLA1IiOUxS2kdEuBzwGDC Z5jcIZA

James, F. J. (2010) The Media and the Anti-Corruption Crusade in Kenya: Weighing the Achievements, Challenges, and Prospects. American University International Law Review, 26, 33-88.

Owiny, P. (2009). Efficacy of the Policy, Legal and Institutional Frameworks for Combating Corruption in Kenya. Nairobi: University of Nairobi Library. http://erepository.uonbi.ac.ke/bitstream/handle/11295/15311/ABSTRACT.pdf?sequenc $\underline{\mathrm{e}=3}$

Pepys, M. N. (2003). Corruption and the Justice Sector.

Rehnquist, W. H. (1973). Sense and Nonsense about Judicial Ethics. 28 Rec. 694.

Søreide, T., \& Williams, A. (2013). Corruption, Grabbing and Development: Real World Challenges. Cheltenham: Edward Elgar Publishing.

Stratos, P. (2009). Corruption in Our Courts: What It Looks Like and Where It Is Hidden. The Yale Law Journal, 118, 1900-1943. https://www.jstor.org/stable/40389524

Tolchin, M., \& Tolchin, S. J. (2015). Pinstripe Patronage. Abingdon-on-Thames: Routledge. https://doi.org/10.4324/9781315632827

Transparency International (2016). Corruption Perceptions Index 2016. http://www.ey.com/Publication/vwLUAssets/EY-Transparency-International-Corrupti on-Perceptions-Index-2016/\$FILE/EY-Transparency-International-Corruption-Percep tions-Index-2016.pdf

Tseki, L. (2014). Corruption: A Moral Issue.

Tzu, S. (1953). The Art of War. Leicester: Allandale Online Publishing.

UNODC (2001). Commentary on the Bangalore Principles of Judicial Conduct.

Westra, L., \& Lemons, J. (2012). Perspectives on Ecological Integrity (p. 225). Berlin: Springer Science \& Business Media. 